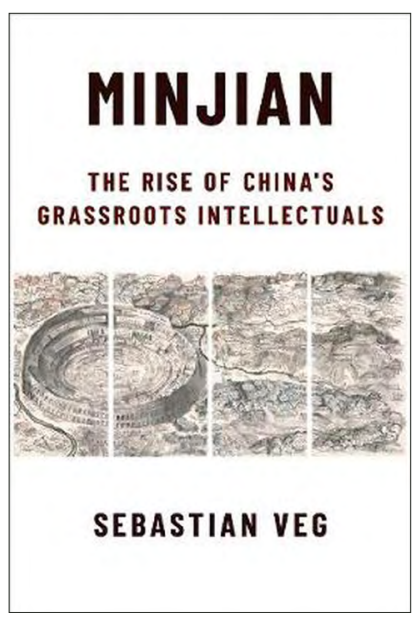

Minjian: The Rise of China's Grassroots Intellectuals (Columbia University Press, 2019).

\section{Revisiting Minjian Intellectuals A Conversation with Sebastian Veg}

$\mathrm{n}$ the past few months, I collaborated with Xu Xibai, a PhD candidate at the University of Oxford, to translate into Chinese Sebastian Veg's groundbreaking book Minjian: The Rise of China's Grassroots Intellectuals (Columbia University Press, 2019). We embarked on this project with the conviction that this translation will not only inspire debate on the role of Chinese intellectuals in the Chinese-speaking world, but also lead the protagonists of the book to reflect on their own positions, ideas, and interventions in the context of an evolving Chinese society. In the following conversation, which also serves as a preface to the Chinese edition of the book, to be published by Lianjing Publishing in Taiwan later this year, Sebastian offers his insights on a number of critical issues, such as support for Donald Trump among Chinese intellectuals; the conditions of non-Han intellectuals in Xinjiang, Tibet, and Inner Mongolia; the anxiety of local intellectuals after the introduction of the National Security Law in Hong Kong; as well as how feminist critique can democratise the study of intellectuals.

Zeng Jinyan: In your book, you study the minjian intellectuals-that is, Chinese thinkers and activists working outside academia and policy institutions. You analyse the alternative publics, semi-publics, and counter-publics created by these intellectuals between the 1990s and middle 2010s, highlighting how these publics are shrinking and now have mostly disappeared. Under the dire circumstances of today, what does research on minjian intellectuals have to offer to both China and the world?

Sebastian Veg: This is a very interesting question, both theoretically and empirically. On the theoretical level, there have been many critical reflections about the theory of public spaces, and their inherently exclusionary dimensions. Several scholars have suggested the notion of 'counter-publics' as a different way of looking at how groups try to establish their presence in public spaces. An important point made by Craig Calhoun is that, strictly speaking, when people work to establish a 'counter-public' through a specific vocabulary and specific venues (physical spaces or publications or communica- 
tion networks), it means that they no longer attempt to participate in the networks of publics that constitute the mainstream public sphere. This meaning of 'counter-public' comes close to the notion of 'counterculture'. It also echoes James Scott's views on 'hidden transcripts'-groups communicating in their own specific ways under the radar of standard communication.

So, on the empirical level, looking at the evolution of the situation in China roughly starting with the Beijing Olympics of 2008, and accelerating after the publication of Document No. 9 in 2013-a leaked Party document that singled out seven types of activities and discourses (including critical history of the People's Republic of China, constitutionalism, investigative journalism) as targets for repression-there is no question that minjian intellectuals and almost all types of critical discourses have been significantly suppressed. Some of those events happened while I was finishing writing the book, and others have taken place since then. Hong Kong, which I argue has always been a kind of 'offshore public sphere' for China, became the most recent space to be directly targeted by the regime. So, there is no question that spaces for non-elite, non-mainstream voices are dwindling.

However, I would not necessarily accept the idea that there is no public space at all. To take a recent example, remember the people shouting from their windows in the Wuhan apartment buildings when Sun Chunlan came to 'inspect' the victory over the COVID-19 epidemic in early March 2020? Another example is Li Wenliang's Weibo account, which has become a virtual memorial. To me, these examples show that people have not entirely given up on the idea of public expression. Of course, you are right that many people have retreated from the public domain; they now limit themselves to closed discursive communities. The state seems quite happy to let likeminded people talk among themselves, for example, in WeChat groups, especially if technology allows the state to keep a close eye on what is being said.

But the minjian moment of the 1990s and early 2000s is not unique in Chinese intellectual history. There have been minjian voices at different times in the twentieth century and probably even before. The New Village Movement (新村运动) in the early 1920s and some of its main proponents like Zhou Zuoren might be an example. The journal Spark (星火), published by the Lanzhou rightists in 1960, was a typical minjian publication. The underground reading groups that emerged among Educated Youths in the early 1970s might be another example. So, I don't think the minjian type of intellectual will disappear. More broadly, I would say that, despite the heavy control of the state, Chinese society continues to evolve in ways that are not always easy to measure and that may still surprise observers. 


\section{ZJ: In recent years, many self-identified 'liberal' intellectuals and minjian intellectuals have openly expressed their support for Donald Trump. How did such a dramatic logical, emotional, and political turn take place? What questions does Trumpism among Chinese intellectuals raise for us?}

SV: This is a subject I am hesitant to discuss because I have not directly studied it. Probably it will require a more detailed typology. Lin Yao has proposed the notion of 'beaconism', which makes sense, since America has historically been a source of inspiration (and disappointment) for Chinese intellectuals, maybe ever since Woodrow Wilson first promised self-determination and then compromised over Chinese claims at the Paris Peace Conference in 1919. But there may be other factors. The extreme identification with American politics of certain Chinese scholars and public intellectuals is of course due to the absence of a 'normal' political life in China. Anti-communism, and disappointment with policies of engagement perceived to be supported by the Democratic Party, has always tilted a group of Chinese intellectuals towards the Republican Party.

Although the Trump supporters can be found in China (as well as Hong Kong and Taiwan), a group of exiles in the United States have played a key role in relaying Trump's message. As we have seen previously in cases like Iran, Afghanistan, or Iraq, politics among small, exiled communities can easily become radicalised in ways that end up being very harmful to the community itself. Some lobbyists have embraced the partisan views of a few politicians who support them. So, it would be interesting to study the networks of information flows: who are the producers and receivers of information about Trump in Chinese?

There is also the question of media. A lot of people around the world no longer search for news from a variety of sources but stick to the streams of news that algorithms earmark for them. This is even more of a problem in China, where censorship is built into the algorithms through which many people access news. On the other hand, some people in China, because of the pervasive censorship and propaganda, are so distrustful of 'mainstream media' that they only refer to some parallel information channels. We know that Epoch Times (大纪元时报) has played a considerable role in raising support for Trump among Chinese-speaking communities in the United States and maybe also in China. So, many people are consuming information flows in such a way that they are never exposed to different sources and perspectives.

Still, I think the phenomenon should not be exaggerated. According to some rough estimates, Trump did not poll higher among Chinese Americans than among American voters in general. The issue of people voting for Trump even though they are direct victims of his policies has been studied more broadly in the US context by Arlie Hochschild in her 2016 book Strangers in Their Own Land. She talks about workers in Louisiana whose health suffers 
directly from Trump's dismantling of environmental protection and of health care, yet who still vote for him. Similarly, you could observe that some pro-Trump Republicans, like Ted Cruz, vetoed a law facilitating asylum for people leaving Hong Kong. The same would apply for dissidents fleeing China. Finally, we should not forget that there are some very lucid observers among Chinese intellectuals who provide nuanced analysis for those who are willing to go beyond the thrill of social media invective.

ZJ: You have studied the radical changes in Hong Kong society in recent years. What is its relationship with Chinese politics? In your research on various social groups in Hong Kong, are there any characteristics and issues that deserve special attention, especially in relation to minjian intellectuals in mainland China?

SV: As I said, Hong Kong has been a kind of offshore public sphere for China ever since Wang Tao fled the Taiping uprising and became the first major Chinese-language newspaper entrepreneur in the city in the second half of the nineteenth century, a few decades before Liang Qichao took on a similar role in Tokyo and Shanghai. Hong Kong has been a crucial place for debate and political dissent at key points throughout the twentieth century, including for intellectuals fleeing the Guomindang regime in the 1930s and the communist regime in the 1950s, like the neo-Confucians who established New Asia College in 1949, as well as after 1989, when Jin Guantao and Liu Qingfeng established the journal Twenty-First Century (二十一世纪) at the Chinese University of Hong Kong (CUHK). So, I would say there is a minjian element to Hong Kong's position as an intellectual centre, in the sense that elite Chinese intellectuals usually looked down on Hong Kong as a 'cultural desert'.

Hong Kong may or may not have had some of the elite cultural institutions that they yearned for, depending on the historical period being referred to, but Hong Kong did have two things: first, a very diverse mosaic of communities from different places in China and beyond China, many of which had their own vibrant cultural life, although the communities themselves may have been quite closed in terms of language and general openness to outsiders. Second, Hong Kong had the legal and economic basis for print capitalism and, especially in the 1950s and 1960s, more broadly, entertainment capitalism including film and music. Hong Kong had relatively lenient censorship laws in colonial times, although overt political activity was discouraged (but newspapers supporting both the Nationalist Party and the Chinese Communist Party survived over the years despite some censorship). Print capitalism allowed many disenfranchised intellectuals to make a living from their pen (the perfect example is Liu Yichang). And, in time, with print entrepreneurs like Louis Cha (Zha Liangyong/Jin Yong), it built up media with a strong reputation for objective reporting as well as good writing. 
It is true that the Hong Kong intellectual scene may have been tilted toward capitalism and in this sense is different from the minjian intellectuals who maintain their distance from both state and market. But Hong Kong also had universities-leaving aside the rather colonial institution that was Hong Kong University, New Asia College opened a road that eventually led to the establishment of CUHK in 1963-and reputed secondary schools, where some intellectuals could teach. Many tried to balance their activities between political and intellectual ideals, educational pursuits, political commentary, and supplementing their income by writing fiction or film scripts.

From the 1960s, Hong Kong also had a productive tension between the party politics that played out on the big geopolitical stage-between Beijing and Taipei; London, Washington, and Moscow-and the local issues that exiled intellectuals did not immediately connect with. The 1970s saw a 'localisation' of intellectual pursuits, with a stronger sense of local identity, growing anticolonial activism, and at the same time the looming question of Hong Kong's future that became acute in the early 1980s. So, the tension between 'high politics' and 'local issues' is again something very typical of minjian intellectuals. Here I would particularly like to refer to Professor Chan Kin-man's moving farewell speech at CUHK, which sketches out his own intellectual itinerary, beginning with local social movements in the 1970s.

\begin{abstract}
ZJ: When I was conducting my postdoctoral research at the University of Haifa, my advisor, Nimrod Baranovitch, introduced me to the study of 'ethnic minority' writers, artists, and scholars. So, I began to pay particular attention to cultural and intellectual productions in Chinese language by ethnic (Mongolian, Uyghur, and Tibetan) intellectuals, on the stories of their own ethnic communities. Although your research does not cover this group, they share many of the same characteristics as minjian intellectuals. For instance, they are in marginalised social positions, engaged in activism and speaking truth to power, and have faced the risk of being further marginalised. Intellectuals from minority ethnic groups are confronted with the rapid disappearance of their native languages and cultures, as well as a physical experience similar to that of intellectuals in the Jiabiangou Labour Camp in the 1950s. What kind of dialogue could take place between Han and non-Han intellectuals? In other words, what inspiration could the study of minjian intellectuals offer to the study of intellectuals and ethnicity?
\end{abstract}

SV: Thank you for raising this question, since it has become more and more important to pay attention to the situation of non-Chinese people within China (I prefer not to use the term 'minority', since the groups you refer to are or were often a demographic majority in their historical territories before they were subject to annexation or population transfer). I did consider this question initially and therefore I tried to incorporate some discussion of linkages between minjian intellectuals and non-Han intellectuals, especially in connection with the Gongmeng (公盟) report on the events of 
March 2008 in Lhasa. Of course, I could have devoted more time to writings or other projects by Wang Lixiong and Woeser, Ilham Tohti, or Tashi Wangchuk. My main reason for not doing so is that, as someone who pays attention to reading communities and communication networks, my basic assumption would be that their writings in Chinese are part of a larger multilinguistic discussion, which is best studied by scholars with at least basic understanding of Tibetan, Uyghur, or Mongolian. There are already many problems with the public sphere in China, and the marginalisation of voices not writing in Chinese is something that I would not feel comfortable accepting and somehow normalising in my work just because of my own linguistic limitations. Of course, it is possible to study individuals and their role as linguistic brokers or hubs. But in this book, I wanted to move away from individuals and focus on networks and reading publics. That is why I feel that to do this study properly would have required skills that I do not have.

\section{ZJ: Your book emphasises a gender perspective. It is pioneering, even in the study of intel- lectuals. Could you briefly review the relationship between gender and intellectual studies on a historical, conceptual, and empirical level? In the study of Chinese intellectuals, how does feminist critique help to democratise both the theme and the research methodology?}

SV: On the role of women minjian intellectuals, I have learned a lot from your book, as well as your articles on Ai Xiaoming. Just like the public sphere paradigm, the field of intellectual studies has historically suffered from a gender bias. In Intellectuals and Their Publics, a 2009 collection of essays exploring various aspects of studies on intellectuals edited by Christian Fleck, Andreas Hess, and E. Stina Lyon, there is a chapter by Mary Evans provocatively titled 'Can Women Be Intellectuals?'. It aims not to question the participation of women in the Enlightenment project that defined European intellectual life since the eighteenth century, but rather to highlight the gendered asymmetries in the institutionalisation of the role and status of intellectuals. While women were often the object of Enlightenment discourse-including among early twentieth-century proponents of social reforms in China (foot-binding is the obvious example)-when women themselves took on the role of speaking subjects, their enlightenment discourse rarely claimed a gendered perspective. The interactions between gender and the boundaries of the public and private realms are a particularly rich area for further inquiry.

In recent years, there have been some interesting studies in Chinese intellectual history, which I hope will be pursued further. He-Yin Zhen, whose role as a feminist anarchist in the late Qing has long been known, is at the centre of The Birth of Chinese Feminism, a very enlightening volume edited by Lydia Liu, Rebecca Karl, and Dorothy Ko. An Unfinished Republic, David Strand's 2011 book on the 1911 Revolution focuses on another very revealing incident: at the 
founding congress of the Guomindang in 1912, Song Jiaoren was slapped in the face by Tang Qunying, one of the active suffragists in the party, protesting Sun Yat-sen's compromise with Yuan Shikai on the issue of including women's suffrage in the new constitution. Of course, we know that Ding Ling denounced gender hierarchies in Yan'an. So, I think a lot more work can be done in this direction in intellectual history. Beyond intellectuals, there is a strong interest in women's roles in various stages of China's twentieth-century history-in particular, Gail Hershatter's and Guo Yuhua's separate oral history projects on women working on collective farms in the Mao era, or Hershatter's work on sex-workers in Shanghai. As you put it, I believe that feminist critique can contribute to 'democratising' methods-that is, paying more attention to non-elite sectors of society. I definitely look forward to reading your coming work on this topic. 
This text is taken from Made in China Journal: Volume 6, Issue 1, 2021, edited by Ivan Franceschini and Nicholas Loubere, published 2021 by ANU Press, The Australian National University, Canberra, Australia.

doi.org/10.22459/MIC.06.01.2021.22 